\title{
Early Growth Response 1 Induces Epithelial-to-mesenchymal Transition via Snail
}

\author{
Hyun Min Jeon ${ }^{1}$, Su Yeon Lee ${ }^{1}$, Min Kyung Ju${ }^{1}$, Hye Gyeong Park ${ }^{2}$ and Ho Sung Kang ${ }^{1 *}$ \\ ${ }^{1}$ Department of Molecular Biology, College of Natural Sciences, ${ }^{2}$ Nanobiotechnology Center, Pusan National University, Busan 609-735, Korea
}

Received July 25, 2013 /Revised August 8, 2013 /Accepted August 8, 2013

\begin{abstract}
The epithelial-to-mesenchymal transition (EMT) plays an essential role in embryogenesis and is involved in tumor metastasis and invasion; it significantly contributes to tumor progression and aggressiveness. The EMT is characterized by a loss of epithelial cell polarity as a result of the reduced expression of epithelial E-cadherin, a hallmark of the EMT, and the acquisition of mesenchymal-like cell morphology. Reactive oxygen species (ROS) such as $\mathrm{O}_{2}^{-}, \mathrm{H}_{2} \mathrm{O}_{2}$, and $\mathrm{OH}^{-}$have been demonstrated to induce the EMT; although Snail is involved in ROS-induced EMT by transcriptionally repressing E-cadherin, its mechanism is not fully understood. In this study, we examined the effects of early growth response 1 (Egr-1) overexpression in noninvasive breast tumor cell line MCF-7 cells. Upon Egr-1 overexpression, MCF-7 cells lost epithelial cell polarity and became more spindle-shaped, indicating that Egr-1 may induce EMT. We found that Snail is implicated in Egr-1 induced EMT. We further demonstrate that the Egr-1-Snail axis is activated by ROS and plays a critical role(s) in ROS-induced EMT.
\end{abstract}

Key words : Egr-1, epithelial-to-mesenchymal transition (EMT), Snail, E-cadherin, reactive oxygen species (ROS)

\section{Introduction}

EMT plays an essential role in embryogenesis and is involved in tumor metastasis, invasion, and angiogenesis [20, 25, 31]. During EMT, epithelial cells lose their polarity by reducing the expression of epithelial E-cadherin, a hallmark of EMT, and acquire mesenchymal-like cell morphology [20, $25,31]$. EMT can be induced by several tumor-stimulating cytokines, such as transforming growth factor (TGF)- $\beta$, Notch, hedgehog, and Gli in many invasive human carcinomas [31]. Several transcription factors have been implicated in the transcriptional repression of E-cadherin, including zinc finger proteins of the Snail/Slug family, Twist1, Twist2, SEF1/ZEB1, ZEB2/Sip1, and the basic helix-loop-helix factor $\mathrm{E} 12 / \mathrm{E} 47[9,23]$. Snail is a zinc finger transcription factor that induces the EMT by directly repressing E-cadherin expression [25]. Snail-expressing epithelial cells exhibit migratory and invasive properties during tumor progression $[20,25,37]$. Snail is highly expressed in the invasive regions

\footnotetext{
*Corresponding author

Tel : +82-51-510-2275, Fax : +82-51-513-9258

E-mail : hspkang@pusan.ac.kr

This is an Open-Access article distributed under the terms of the Creative Commons Attribution Non-Commercial License (http://creativecommons.org/licenses/by-nc/3.0) which permits unrestricted non-commercial use, distribution, and reproduction in any medium, provided the original work is properly cited
}

of many different types of carcinomas [5, 29, 35]. RNA interference-mediated Snail silencing results in a reduced tumor growth in vivo [22]. In addition, Snail exerts mammary tumor recurrence-promoting activities [18]. Recently, ROS such as $\mathrm{O}_{2}^{-}, \mathrm{H}_{2} \mathrm{O}_{2}$ and $\mathrm{OH}^{-}$have been demonstrated to induce EMT $[6,7,14,19,23,24,26]$. By ROS-mediated EMT, invasion, and metastasis, cancer cells could escape from oxidative-damaged tumors tissues [14]. ROS are produced by tumor microenvironments such as GD and hypoxia [31]. Although Snail is involved in ROS-induced EMT by transcriptionally repressing E-cadherin [28], its mechanism is not fully understood.

Early growth response-1 (Egr-1) is a Cys2-His2-type zincfinger transcription factor $[1,30]$. This zinc-finger protein is an immediate early growth response gene known to be induced by a broad range of extracellular stimuli such as anti-cancer drugs, growth factors, irradiation, hypoxia, and oxidative stress. It is involved in the regulation of cell proliferation, apoptosis, growth arrest, differentiation, transformation, senescence, and cancer development. Egr-1 regulates positively or negatively tumor growth $[1,2,17,30$, $32-34,36]$. It acts as a tumor suppressor; however, many new evidences revealed that Egr-1 promotes cancer progression. Egr-1 can induce apoptosis by directly regulating tumor suppressors such as p53 [3]. In addition, Egr-1 plays a critical role(s) in hypoxia-induced tumor progression, survival, and angiogenesis [13, 21, 27, 38]. Although sustained Egr-1 ex- 
Table 1. shRNA target sequences used in this study

\begin{tabular}{ll}
\hline Genes & Target sequence $5^{\prime}$ to $3^{\prime}$ \\
\hline Con shRNA & AATTCTCCGAACGTGTCACGT \\
Egr-1 shRNA & AAGTTACTACCTCTTATCCAT \\
Snail shRNA & GCGAGCTGCAGGACTCTAA \\
\hline
\end{tabular}

pression induces anti-angiogenesis, growth arrest, and apoptosis, transient induction of Egr-1 is known to activate angiogenesis [16]. In addition, Egr-1 has been implicated in GD-induced necrosis and tumor progression [10].

In this study, we show that Egr-1 is implicated in ROS-induced EMT via Snail activation. In addition, we show that Egr-1-Snail axis plays a critical role(s) in ROS-induced tumor progression through regulating EMT.

\section{Materials and Methods}

\section{Cell culture and ROS treatment}

MCF-7 was obtained from the American Type Culture Collection (ATCC, Manassas, VA, USA; authenticated by short tandem repeat profiling), and maintained in EMEM supplemented with $10 \%(\mathrm{v} / \mathrm{v})$ heat-inactivated fetal bovine serum (FBS, Hyclone, Logan, UT, USA) and $1 \%$ penicillin-streptomycin (PS, Hyclone, Logan, UT, USA) in a $37^{\circ} \mathrm{C}$ humidified incubator with $5 \% \mathrm{CO}_{2}$. The cells were treated with reactive oxygen species [ROS, including $200 \mu \mathrm{M}$ hydrogen peroxide $\left(\mathrm{H}_{2} \mathrm{O}_{2}\right.$; Sigma, MO, USA $)$ and $10 \mu \mathrm{M}$ menadione (an $\mathrm{O}_{2}^{-}$generator; Sigma, MO, USA)].

\section{Transfection and short hairpin RNA (shRNA) interference}

The expression vectors pcDNA3.1-Egr-1 (provided by Dr. Thomas E. Eling, Laboratory of Molecular Carcinogenesis, National Institute of Environmental Health Sciences, USA) were transfected into MCF-7 cells using jetPEI (Polyplustransfection, SA, USA) according to the manufacturer's instructions. pSUPER vectors expressing shRNA for control, Egr-1, and Snail were generated from target-specific annealed oligonucleotides inserted into the HindIII and BgIII sites of pSUPER.gfp/neo (Oligoengine Platform, Seattle, WA) (Table 1). All target sequences were designed and verified as specific for Egr-1, and Snail by Blast search against the human genome and transfected using jetPEI.

\section{Western blotting and real-time PCR}

Sodium dodecyl sulfate-polyacrylamide gel electrophoresis (SDS-PAGE) and Western blotting with antibodies to Egr-1, Snail, and E-cadherin (Santa Cruz, CA, USA), and a-tubulin (Biogenex, CA) was performed as described previously [10-12]. Transcript levels were assessed with real-time quantitative PCR with the primers for Egr-1, Snail,

Table 2. Primer sequences used in this study

\begin{tabular}{|c|c|c|c|c|}
\hline & & & Sequence $5^{\prime}$ to $3^{\prime}$ & Annealing ${ }^{\circ} \mathrm{C}$ \\
\hline \multicolumn{5}{|l|}{ Real time PCR } \\
\hline \multirow[t]{2}{*}{$\beta$-actin } & NM_001101.3 & sense & АСTCTTCCAGCСTTCCTTCC & \\
\hline & & antisense & TGTTGGCGTACAGGTCTTTG & \\
\hline \multirow[t]{2}{*}{ Egr-1 } & NM_001964.2 & sense & AGGACAGGAGGAGGAGATGG & 62 \\
\hline & & antisense & GGAAGTGGGCAGAAAGGATTG & \\
\hline \multirow[t]{2}{*}{ Snail } & NM_005985 & sense & ATCGGAAGCCTAACTACAGC & 55 \\
\hline & & antisense & CAGAGTCCCAGATGAGCATT & \\
\hline \multirow[t]{2}{*}{ E-cadherin \#1 } & NM_004360 & sense & GATTTTGAGGCCAAGCAGCA & 55 \\
\hline & & antisense & AGATGGGGGCTTCATTCACA & \\
\hline \multirow[t]{2}{*}{ E-cadherin \#2 } & & sense & AGCTGGACAGGGAGGATTTT & 55 \\
\hline & & antisense & TTCGAGGTTCTGGTATGGGG & \\
\hline \multicolumn{5}{|l|}{ ChIP assay } \\
\hline \multirow[t]{2}{*}{ Egr-1 binding site \#1 } & & sense & GTGCGTTTCCCTCGTCAATG & 62 \\
\hline & & antisense & GACACCTGACCTTCCGACG & \\
\hline \multirow[t]{2}{*}{ Egr-1 binding site \#2 } & & sense & CCAGGGGGCGTCAGAAG & 62 \\
\hline & & antisense & GACGTCGAGCGAAGCGAG & \\
\hline \multirow[t]{2}{*}{ Egr-1 binding site \#3 } & & sense & GGGCGTGGCAGATAAGG & 62 \\
\hline & & antisense & AGAAGAACCACTCGCTAGGC & \\
\hline \multirow[t]{2}{*}{ E-cadherin E4 } & & sense & TCCATTTCTTGGTCTACGCC & 55 \\
\hline & & antisense & CACCTTCAGCCAACCTGTTT & \\
\hline
\end{tabular}


Table 3. Putative Egr-1 binding site and Snail binding site (E-box) in promoter region

\begin{tabular}{|c|c|c|c|}
\hline Gene & Egr-1 binding site & Snail binding site & Positions from transcription start site \\
\hline \multirow[t]{3}{*}{ Snail } & $\# 1$ & & ${ }^{430}$ CGCCCCCTCCC-......-GCGGGGGCG ${ }^{-402}$ \\
\hline & $\# 2$ & & ${ }^{-362}$ CAGGGGGCG $^{-354}$ \\
\hline & $\# 3$ & & ${ }^{-59}$ CGCCCCTCC $^{-51}$ \\
\hline \multirow[t]{4}{*}{ E-cadherin } & & E1 & ${ }^{465}$ CACCTG $^{-460}$ \\
\hline & & E2 & ${ }^{-79}$ CAGGTG $^{-74}$ \\
\hline & & E3 & ${ }^{-28}$ CACCTG $^{-23}$ \\
\hline & & E4 & ${ }^{+22}$ CACCTG $^{+27}$ \\
\hline
\end{tabular}

E-cadherin, and $\beta$-actin (Table 2). Quantitative real-time PCR was conducted in a LightCycler (Roche Diagnostics, Mannheim, Germany) using a SYBR Green kit (Roche Diagnostics).

\section{Chromatin immunoprecipitation (ChIP) assay}

ChIP assays were performed using a ChIP assay kit (Millipore, Billerica, MA, USA). IgG or anti-Egr-1, anti-Snail (Santa Cruz, CA, USA) was used to immunoprecipitate DNA-containing complexes. ChIP-enriched DNA was analyzed by PCR using primers (Table 2) complementary to the promoter regions containing Egr-1 and Snail binding site, respectively (Table 3 ).

\section{Measurement of circularity}

Circularity was measured with the Axiovision LE software (Release 4.8 version)'s Measure command that calculates object circularity using the formula circularity $=4 \pi$ (area/perimeter ${ }^{2}$ ). Circularity value of 1.0 indicates a perfect circle. As the value approaches 0.0 , it indicates an increasingly elongated polygon.

\section{Statistical analysis}

Data were analyzed by the Student's t-test and $p<0.05$ was considered statistically significant.

\section{Results and Discussion}

\section{Egr-1 induces EMT via Snail activation}

Egr-1 is involved in tumor cell proliferation and apoptosis. We examined the effects of Egr-1 overexpression in noninvasive breast tumor cell line MCF-7 cells. Upon Egr-1 overexpression, MCF-7 cells lost epithelial cell polarity and became more spindle-shaped, indicating that Egr-1 may induce EMT (Fig. 1A). Spindle quantification also showed Egr-1 induction of EMT (Fig. 1B). Egr-1 overexpression also decreased the levels of E-cadherin, one of the hallmarks of EMT, as revealed by real-time PCR (Fig. 1C) and Western analysis (Fig. 1D). We examined if Egr-1 directly regulates the E-cadherin expression. However, Egr-1 binding sites were not found in the promoter of E-cadherin. Thus, we postulated that Egr-1 may reduce E-cadherin indirectly by activating other transcriptional factors. Several transcription factors such as Snail/Slug, Twist1, Twist2, SEF1/ZEB1, ZEB2/Sip1, and E12/E47 have been implicated in EMT and the transcriptional repression of E-cadherin [9, 23]. Among these transcriptional factors, Snail is a typical transcription factor for EMT and E-cadherin downregulation [25]. Thus, we examined whether Snail is involved in Egr-1-induced EMT. Snail shRNA prevented the EMT (Fig. 1A and B), indicating that Egr-1 may induce EMT via Snail activation. In addition, Egr-1 overexpression increased Snail levels (Fig. 1C and D), indicating that Egr-1 acts as an upstream mediator of Snail activation. Next, we checked whether Egr-1 regulates Snail expression through directly binding to the promoter of Snail. Four Egr-1 binding sites were found in the human Snail promoter (Fig. 2A). Egr-1 overexpression enhanced the binding of Egr-1 to the sites of the Snail promoter (Fig. 2A) indicating expression of Snail by Egr-1. And then we performed ChIP assay to examine in vivo binding of Snail to the promoter of E-cadherin. There are 4 E-boxes in human E-cadherin promoter that can be recognized by Snail $[4,15] ;-465 /-460,-79 /-74,-28 /-23,+22 /+27$ from transcription start site (Table 3 ). Snail has been shown to bind to the E-boxes 1, 3, 4, but not to E-box 2 and suppressed E-cadherin gene activity; E-box 4 had the most repression ability compared with other E-boxes on human E-cadherin gene expression [4, 15]. Therefore, ChIP analysis of Egr-1 and Snail on the E-cadherin promoter was conducted with E-box 4 region. Egr-1 overexpression enhanced the binding of Snail to the E-box sites of the E-cadherin (Fig. 2B), indicating that Egr-1-induced Snail protein interacts directly with E-box 4 in the E-cadherin promoter. Our results showed that Egr-1 induces EMT by activating Snail. 
A

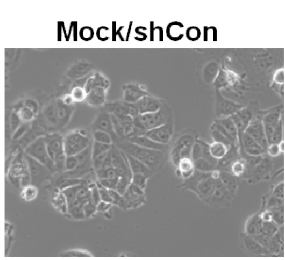

Egr-1/shCon

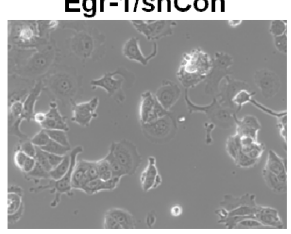

C

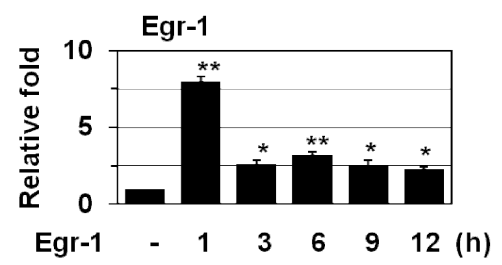

Mock/shSnail

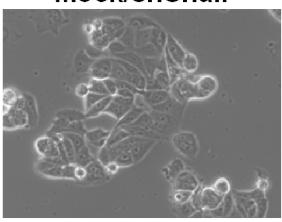

Egr-1/shSnail

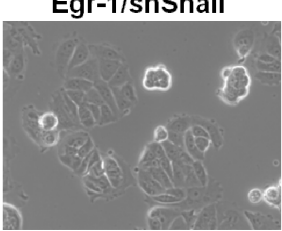

B
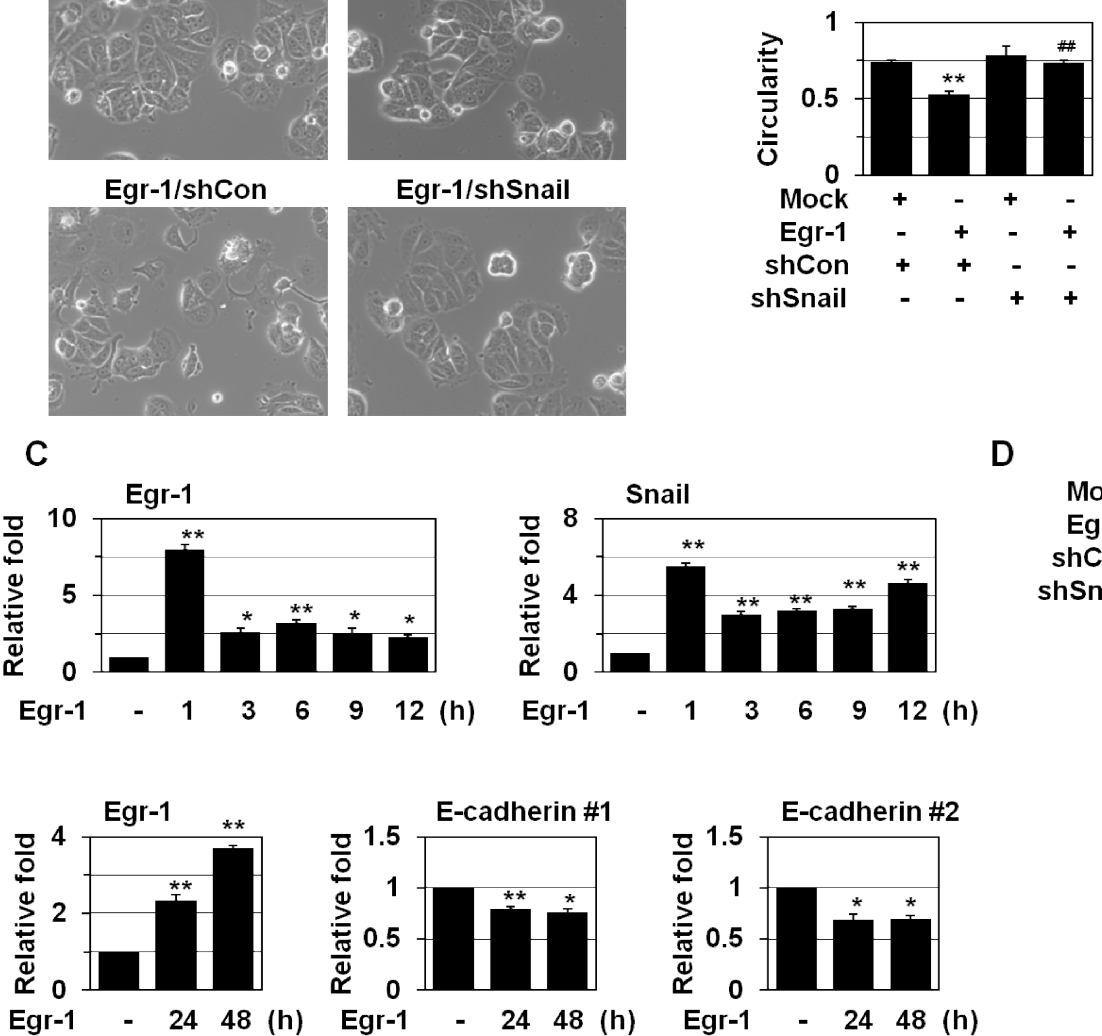

D
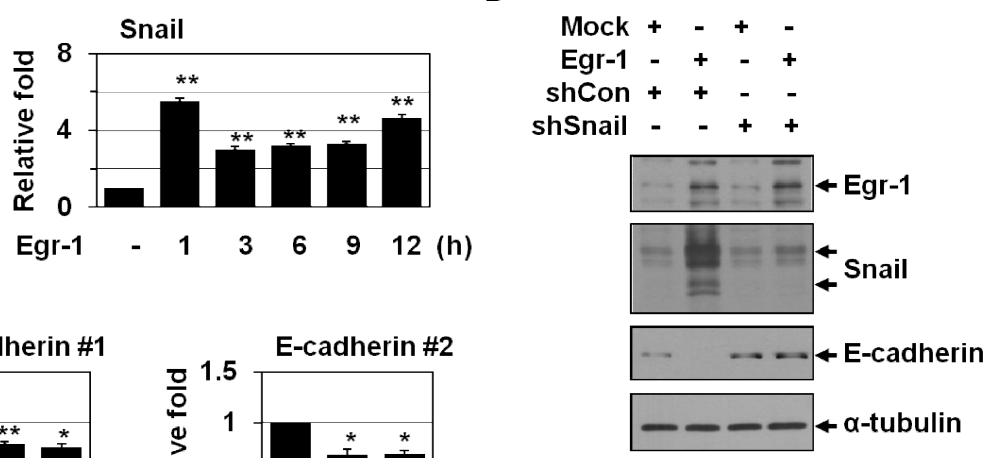

Fig. 1. Egr-1 induces EMT via Snail activation. (A) MCF-7 cells were cotransfected with Egr-1 and Snail shRNA for 2 days. The cell morphology was observed under a phase-contrast microscope (X200). (B) Images were then analyzed by circularity calculation. Circularity value of 1.0 indicates a perfect circle. As the value approaches 0.0 , it indicates an increasingly elongated polygon. The results (77-126 cells in each group) are mean \pm SE. ${ }^{* *} p<0.01$ versus control; ${ }^{\# \#} p \ll 0.01$ versus Egr-1. (C) MCF-7 cells were transfected with Egr-1 for the indicated times and then analyzed by real-time PCR using primers for Egr-1, Snail, E-cadherin (\#1, \#2) and $\beta$-actin. ${ }^{*} p<0.05,{ }^{* *} p<0.01$ versus mock. (D) MCF-7 cells were cotransfected with Egr-1 and Snail shRNA for the 4 days. The cells were then analyzed by Western blotting for Egr-1, Snail, E-cadherin, and a-tubulin.

\section{Egr-1-Snail cascade is also involved in ROS- induced EMT}

Egr-1 and Snail expression has been shown to be redoxsensitive [10,11]. As shown in Fig. 3A and 3B, Egr-1, and Snail levels were increased by ROS treatment. Egr-1 shRNA prevented ROS-induced Snail expression (Fig. 3B), indicating that Egr-1 acts as an upstream mediator for ROS-induced Snail expression. ROS is known to induce EMT [14]. Thus, we examined the relevance between ROS-induced EMT and these genes. Upon ROS treatment, MCF-7 cells exhibited the phenotypic changes including loss of cell polarity and intercellular adhesion and increased formation of pseudopodia (Fig. 3C). Spindle quantification also showed ROS induction of EMT (Fig. 3D). Both Egr-1 shRNA and Snail shRNA blocked ROS-induced EMT phenotype (Fig. 3C and 3D) and E-cadherin downregulation (Fig. 3B), indicating that the
Egr-1-Snail cascade is implicated in ROS-induced EMT. Thus, Egr-1 appeared to regulate ROS-induced EMT via induction of the E-cadherin repressor Snail (Fig. 3E).

Egr-1 has been implicated in tumor cell death, growth, invasion, and angiogenesis. In this study, show a novel function of Egr-1 that may contribute to tumor progression; to induce EMT (Fig. 1A and 3B). Egr-1 induces EMT with downregulation of E-cadherin, a hallmark of EMT (Fig. 1C and 3D). Snail appeared to act as a mediator of Egr-1-induced EMT (Fig. 1 and 2). Egr-1 has been implicated in HGFinduced cell scattering, migration, and invasion via Snail activation [8]. ROS have been demonstrated to induce EMT and Snail is known to be implicated in ROS-induced EMT. We showed that the Egr-1-Snail axis is activated by ROS and plays a critical role(s) in ROS-induced EMT. Recently, we showed that Snail suppresses mitochondrial respiration 
A

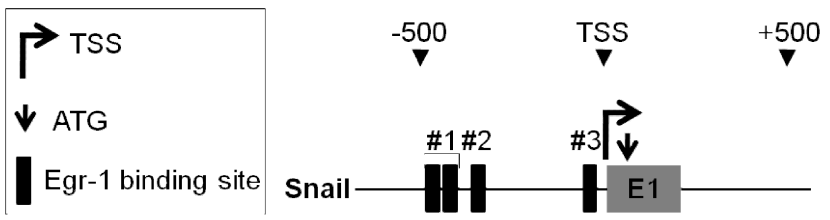

TF 2 d

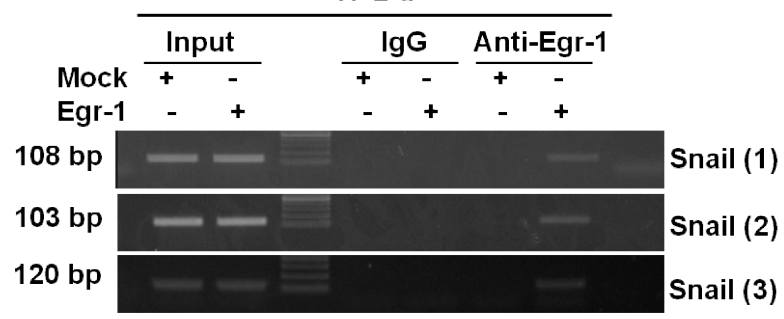

B

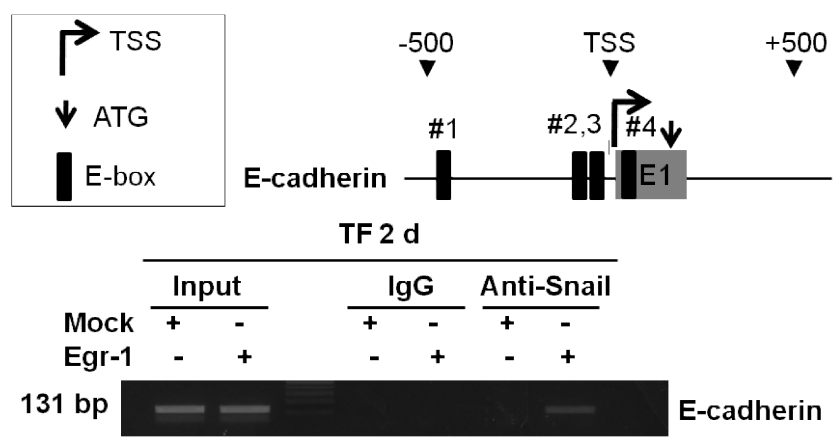

Fig. 2. Egr-1-induced Snail represses the expression of E-cadherin. (A) A schematic model of the human Snail proximal promoter region. The black boxes represent Egr-1 binding sites. MCF-7 cells were transfected with Egr-1 for the 2 days. ChIP assays were performed using IgG or Egr-1 antibodies and ChIP-enriched DNA was analyzed by PCR using the appropriate primers. (B) A schematic model of the human E-cadherin proximal promoter region. The black boxes represent E-boxes. MCF-7 cells were transfected with Egr-1 for the 2 days. ChIP assays were performed using IgG or Snail antibodies and ChIP-enriched DNA was analyzed by PCR using the E-cadherin primer. and cytochrome $\mathrm{C}$ oxidase (COX) activity by inhibiting the expression of 3 COX subunits, namely, COXVIc, COXVIIa, and COXVIIc. In addition, Snail induces a glycolytic switch via increased glucose consumption and lactate production [11]. Thus, Egr-1 may induce glycolytic switch by Snail activation, which remains to be investigated.

\section{Acknowledgements}

This work was supported by a 2-Year Research Grant of Pusan National University. We thank Dr. Thomas E. Eling (Laboratory of Molecular Carcinogenesis, National Institute of Environmental Health Sciences, USA) for providing pcDNA3.1-Egr-1.

\section{References}

1. Adamson, E. D. and Mercola, D. 2002. Egr1 transcription factor: multiple roles in prostate tumor cell growth and survival. Tumour Biol 23, 93-102.

2. Ahmed, M. M. 2004. Regulation of radiation-induced apoptosis by early growth response- 1 gene in solid tumors. Curr Cancer Drug Targets 4, 43-52.
3. Baron, V., Adamson, E. D., Calogero, A., Ragona, G. and Mercola, D. 2006. The transcription factor Egr1 is a direct regulator of multiple tumor suppressors including TGFbeta1, PTEN, p53, and fibronectin. Cancer Gene Ther 13, 115-124.

4. Batlle, E., Sancho, E., Franci, C., Dominguez, D., Monfar, M., Baulida, J. and Garcia De Herreros, A. 2000. The transcription factor snail is a repressor of E-cadherin gene expression in epithelial tumour cells. Nat Cell Biol 2, 84-89.

5. Blanco, M. J., Moreno-Bueno, G., Sarrio, D., Locascio, A., Cano, A., Palacios, J. and Nieto, M. A. 2002. Correlation of Snail expression with histological grade and lymph node status in breast carcinomas. Oncogene 21, 3241-3246.

6. Cannito, S., Novo, E., di Bonzo, L. V., Busletta, C., Colombatto, S. and Parola, M. 2010. Epithelial-mesenchymal transition: from molecular mechanisms, redox regulation to implications in human health and disease. Antioxid Redox Signal 12, 1383-1430.

7. Cat, B., Stuhlmann, D., Steinbrenner, H., Alili, L., Holtkotter, O., Sies, H. and Brenneisen, P. 2006. Enhancement of tumor invasion depends on transdifferentiation of skin fibroblasts mediated by reactive oxygen species. J Cell Sci 119, 27272738.

8. Grotegut, S., von Schweinitz, D., Christofori, G. and Lehembre, F. 2006. Hepatocyte growth factor induces cell scattering through MAPK/Egr-1-mediated upregulation of Snail. EMBO J 25, 3534-3545. 
A
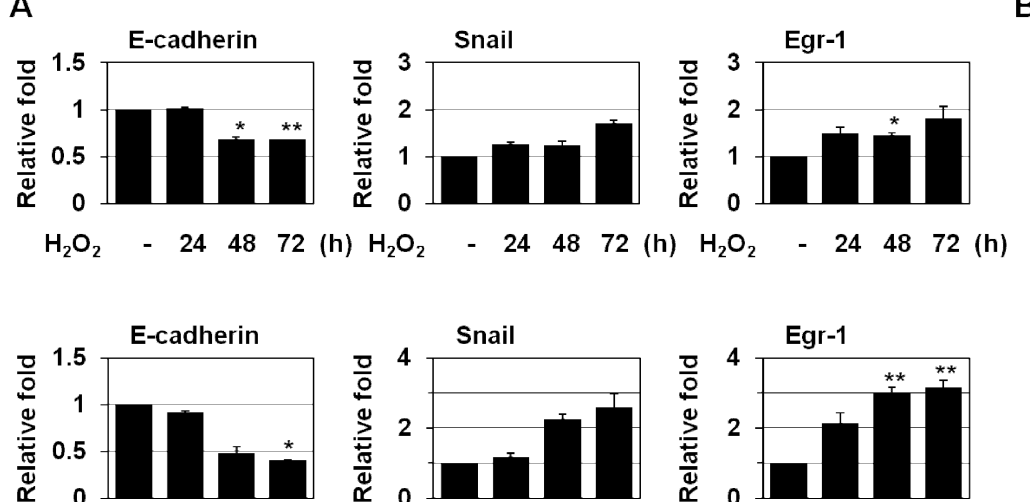

$\mathrm{O}_{2}^{-} \quad-244872($

C
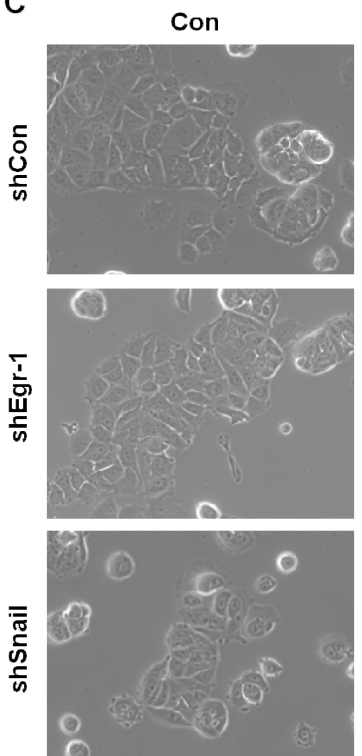

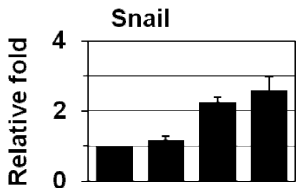

$\mathrm{O}_{2}^{-} \quad-244872(\mathrm{~h})$

$200 \mu \mathrm{M} \mathrm{H}_{2} \mathrm{O}_{2}$
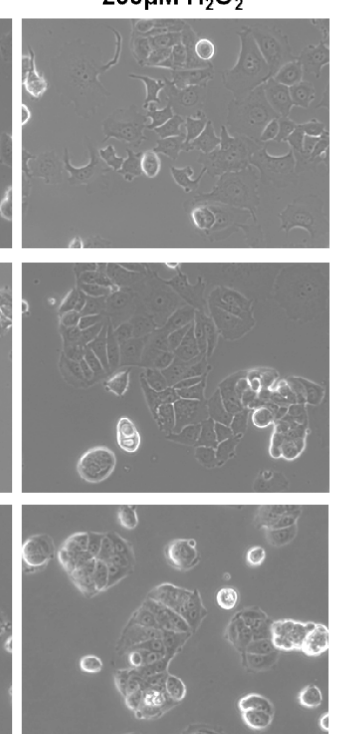

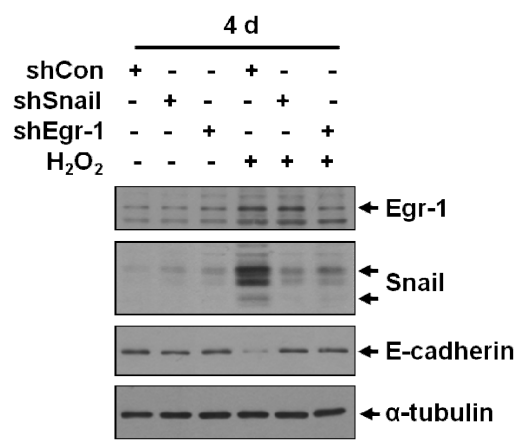

Fig. 3. Egr-1-Snail cascade is also involved in ROS-induced EMT. (A) MCF-7 cells were treated with $\mathrm{H}_{2} \mathrm{O}_{2}(200 \mu \mathrm{M})$ or menadione $\left(\mathrm{O}_{2}^{-}, 10 \mu \mathrm{M}\right)$ for the indicated times and then analyzed by real-time PCR using primers for Egr-1, Snail, E-cadherin and $\beta$-actin. ${ }^{*} p<0.05$, ${ }^{* *} p<0.01$ versus untreated. (B) MCF-7 cells were transfected with control, Egr-1, or Snail shRNA and then treated with $\mathrm{H}_{2} \mathrm{O}_{2}(200 \mu \mathrm{M})$ for 4 days. The cells were then analyzed by Western blotting for Egr-1, Snail, E-cadherin, and a-tubulin. (C) MCF-7 cells were transfected with control, Egr-1, or Snail shRNA and then treated with $\mathrm{H}_{2} \mathrm{O}_{2}(200 \mu \mathrm{M})$ for 3 days. The cell morphology was then observed under a phase-contrast microscope (X200). (D) Images were then analyzed by circularity calculation. Circularity value of 1.0 indicates a perfect circle. As the value approaches 0.0 , it indicates an increasingly elongated polygon. The results (58-118 cells in each group) are mean \pm SE. ${ }^{* *} p<0.01$ versus untreated; ${ }^{\# \#} p<0.01$ versus control shRNA. (E) Under oxidatively stressed conditions, Snail is activated by Egr-1. Egr-1 is induced by ROS and regulates ROS-induced EMT via induction of the E-cadherin repressor Snail.

9. Hussain, S. P., Hofseth, L. J. and Harris, C. C. 2003. Radical causes of cancer. Nat Rev Cancer 3, 276-285.

10. Jeon, H. M., Lee, S. Y., Ju, M. K., Kim, C. H., Park, H. G. and Kang, H. S. 2013. Early growth response 1 regulates glucose deprivation-induced necrosis. Oncol Rep 29, 669-675.

11. Lee, S. Y., Jeon, H. M., Ju, M. K., Kim, C. H., Yoon, G., Han, S. I., Park, H. G. and Kang, H. S. 2012. Wnt/Snail signaling regulates cytochrome $\mathrm{c}$ oxidase and glucose metabolism. Cancer Res 72, 3607-3617.

12. Lee, S. Y., Jeon, H. M., Kim, C. H., Ju, M. K., Bae, H. S.,
Park, H. G., Lim, S. C., Han, S. I. and Kang, H. S. 2011. Homeobox gene Dlx-2 is implicated in metabolic stress-induced necrosis. Mol Cancer 10, 113.

13. Liao, H., Hyman, M. C., Lawrence, D. A. and Pinsky, D. J. 2007. Molecular regulation of the PAI-1 gene by hypoxia: contributions of Egr-1, HIF-1alpha, and C/EBPalpha. FASEB J 21, 935-949.

14. Lim, S. O., Gu, J. M., Kim, M. S., Kim, H. S., Park, Y. N., Park, C. K., Cho, J. W., Park, Y. M. and Jung, G. 2008. Epigenetic changes induced by reactive oxygen species in 
hepatocellular carcinoma: methylation of the E-cadherin promoter. Gastroenterology 135, 2128-2140, e2121-2128.

15. Liu, Y. N., Lee, W. W., Wang, C. Y., Chao, T. H., Chen, Y. and Chen, J. H. 2005. Regulatory mechanisms controlling human E-cadherin gene expression. Oncogene 24, 8277-8290.

16. Lucerna, M., Pomyje, J., Mechtcheriakova, D., Kadl, A., Gruber, F., Bilban, M., Sobanov, Y., Schabbauer, G., Breuss, J., Wagner, O., Bischoff, M., Clauss, M., Binder, B. R. and Hofer, E. 2006. Sustained expression of early growth response protein-1 blocks angiogenesis and tumor growth. Cancer Res 66, 6708-6713.

17. Mahalingam, D., Natoni, A., Keane, M., Samali, A. and Szegezdi, E. 2010. Early growth response-1 is a regulator of DR5-induced apoptosis in colon cancer cells. Br J Cancer 102, 754-764.

18. Moody, S. E., Perez, D., Pan, T. C., Sarkisian, C. J., Portocarrero, C. P., Sterner, C. J., Notorfrancesco, K. L., Cardiff, R. D. and Chodosh, L. A. 2005. The transcriptional repressor Snail promotes mammary tumor recurrence. Cancer Cell 8, 197-209.

19. Mori, K., Shibanuma, M. and Nose, K. 2004. Invasive potential induced under long-term oxidative stress in mammary epithelial cells. Cancer Res 64, 7464-7472.

20. Nieto, M. A. 2002. The snail superfamily of zinc-finger transcription factors. Nat Rev Mol Cell Biol 3, 155-166.

21. Nishi, H., Nishi, K. H. and Johnson, A. C. 2002. Early Growth Response-1 gene mediates up-regulation of epidermal growth factor receptor expression during hypoxia. Cancer Res 62, 827-834.

22. Olmeda, D., Jorda, M., Peinado, H., Fabra, A. and Cano, A. 2007. Snail silencing effectively suppresses tumour growth and invasiveness. Oncogene 26, 1862-1874.

23. Pani, G., Galeotti, T. and Chiarugi, P. 2010. Metastasis: cancer cell's escape from oxidative stress. Cancer Metastasis ReV 29, 351-378.

24. Pani, G., Giannoni, E., Galeotti, T. and Chiarugi, P. 2009. Redox-based escape mechanism from death: the cancer lesson. Antioxid Redox Signal 11, 2791-2806.

25. Peinado, H., Olmeda, D. and Cano, A. 2007. Snail, Zeb and bHLH factors in tumour progression: an alliance against the epithelial phenotype? Nat Rev Cancer 7, 415-428.

26. Radisky, D. C., Levy, D. D., Littlepage, L. E., Liu, H., Nelson, C. M., Fata, J. E., Leake, D., Godden, E. L., Albertson, D. G., Nieto, M. A., Werb, Z. and Bissell, M. J. 2005. Rac1b and reactive oxygen species mediate MMP-3-induced EMT and genomic instability. Nature 436, 123-127.

27. Rong, Y., Hu, F., Huang, R., Mackman, N., Horowitz, J. M., Jensen, R. L., Durden, D. L., Van Meir, E. G. and Brat, D.
J. 2006. Early growth response gene-1 regulates hypoxia-induced expression of tissue factor in glioblastoma multiforme through hypoxia-inducible factor-1-independent mechanisms. Cancer Res 66, 7067-7074.

28. Shi, D. Y., Xie, F. Z., Zhai, C., Stern, J. S., Liu, Y. and Liu, S. L. 2009. The role of cellular oxidative stress in regulating glycolysis energy metabolism in hepatoma cells. Mol Cancer 8,32 .

29. Sugimachi, K., Tanaka, S., Kameyama, T., Taguchi, K., Aishima, S., Shimada, M., Sugimachi, K. and Tsuneyoshi, M. 2003. Transcriptional repressor snail and progression of human hepatocellular carcinoma. Clin Cancer Res 9, 26572664.

30. Thiel, G. and Cibelli, G. 2002. Regulation of life and death by the zinc finger transcription factor Egr-1. J Cell Physiol 193, 287-292.

31. Thiery, J. P. and Sleeman, J. P. 2006. Complex networks orchestrate epithelial-mesenchymal transitions. Nat $\mathrm{Rev} \mathrm{Mol}$ Cell Biol 7, 131-142.

32. Wagner, M., Schmelz, K., Dorken, B. and Tamm, I. 2008. Transcriptional regulation of human survivin by early growth response (Egr)-1 transcription factor. Int $J$ Cancer $122,1278-1287$.

33. Xie, B., Wang, C., Zheng, Z., Song, B., Ma, C., Thiel, G. and Li, M. 2011. Egr-1 transactivates Bim gene expression to promote neuronal apoptosis. J Neurosci 31, 5032-5044.

34. Yamaguchi, H., Chen, C. T., Chou, C. K., Pal, A., Bornmann, W., Hortobagyi, G. N. and Hung, M. C. 2010. Adenovirus 5 E1A enhances histone deacetylase inhibitors-induced apoptosis through Egr-1-mediated Bim upregulation. Oncogene 29, 5619-5629.

35. Yook, J. I., Li, X. Y., Ota, I., Hu, C., Kim, H. S., Kim, N. H., Cha, S. Y., Ryu, J. K., Choi, Y. J., Kim, J., Fearon, E. R. and Weiss, S. J. 2006. A Wnt-Axin2-GSK3beta cascade regulates Snaill activity in breast cancer cells. Nat Cell Biol 8, 1398-1406.

36. Zagurovskaya, M., Shareef, M. M., Das, A., Reeves, A., Gupta, S., Sudol, M., Bedford, M. T., Prichard, J., Mohiuddin, M. and Ahmed, M. M. 2009. EGR-1 forms a complex with YAP-1 and upregulates Bax expression in irradiated prostate carcinoma cells. Oncogene 28, 1121-1131.

37. Zavadil, J. and Bottinger, E. P. 2005. TGF-beta and epithelial-to-mesenchymal transitions. Oncogene 24, 5764-5774.

38. Zhang, P., Tchou-Wong, K. M. and Costa, M. 2007. Egr-1 mediates hypoxia-inducible transcription of the NDRG1 gene through an overlapping Egr-1/Sp1 binding site in the promoter. Cancer Res 67, 9125-9133. 


\section{초록 : Egr-1-Snail 작용에 의한 epithelial-to-mesenchymal transition 유도}

전현민 ${ }^{1} \cdot$ 이수연 ${ }^{1} \cdot$ 주민경 ${ }^{1} \cdot$ 박혜경 $^{2} \cdot$ 강호성 $^{1 *}$

(부산대학 자연과학대학 분자생물학과, ${ }^{2}$ 한국나노바이오테크놀러지센터)

Epithelial-to-mesenchymal transition (EMT)는 embryogenesis에서 중요한 역할을 하며 tumor metastasis, invasion에도 관여함으로써 tumor progression 및 aggressiveness에 기여한다. EMT는 EMT hallmark인 epithelial E-cadherin의 발현 감소와 mesenchymal-like cell morphology를 획득함으로써 epithelial cell polarity를 잃어버 리는 특징을 가지고 있다. $\mathrm{O}_{2}^{-}, \mathrm{H}_{2} \mathrm{O}_{2}, \mathrm{OH}^{-}$와 같은 활성산소가 EMT를 유도하는 것으로 알려져 있다. Snail이 E-cadherin의 발현을 억제함으로써 ROS에 의한 EMT에 관여하는 것으로 알려져 있으나, 그 기작은 완전히 밝혀 져 있지 않다. 본 연구에서는, noninvasive breast tumor cell line인 MCF-7 세포에 Egr-1을 과발현시킨 후 그 영 향을 조사하였다. Egr-1이 과발현되면, MCF-7 세포는 epithelial cell polarity를 잃고 spindle-shaped로 변화되므 로, Egr-1이 EMT를 유도할 가능성이 대두되었다. 또한 Snail이 Egr-1에 의한 EMT에 관여함을 확인하였다. 나아 가, 본 연구진은 Egr-1-Snail axis가 ROS에 의해 활성화 되고, ROS에 의한 EMT에서 중요한 역할을 함을 발견하 였다. 